\title{
The Potential Role of Osmotic Pressure to Exogenous Application of Phytohormones on Crop Plants Grown under Different Osmotic Stress
}

\author{
Hamdia M. Abd El-Samad \\ Botany Department, Faculty of Science, Minia University, El-Minia, Egypt \\ Email: hamdia10@yahoo.com
}

Received 17 February 2016; accepted 24 April 2016; published 27 April 2016

Copyright (C) 2016 by author and Scientific Research Publishing Inc. This work is licensed under the Creative Commons Attribution International License (CC BY). http://creativecommons.org/licenses/by/4.0/

(c) (i) Open Access

\section{Abstract}

The osmotic pressure represented as a sign of plant tolerance or sensitive to salinity stress. In the following plants, the increase in OP seems to be a manner of defense mechanism to survive. OP increased in shoots of maize, shoot and root of wheat and cotton plants was concomitant with shoot soluble sugar, root soluble protein and shoot and root amino acids of maize plants. However, in wheat the increase in OP was related with increase of root soluble sugar and protein of shoots and roots. In cotton plants, the elevation of $O P$ was run parallel with increase soluble sugar of shoots and roots, shoot soluble protein and root amino acids. The increase in OP was related with a marked and significant reduction in the water content of these plants. However, the decrease in OP of shoot and root of broad bean was related with the reduction of shoots and roots soluble sugar, protein and root amino acids of broad bean. While the OP becomes more or less unchanged in shoots and tended to decrease in root of parsley plants, this concomitant with unchanged trend in the shoots amino acids and reduction in root soluble sugar and root amino acids. Run with previous trend values of $\mathrm{OP}$ and metabolites of parsley plants were related with stable values in shoot water content and reduction in root water content. With $\mathrm{GA}_{3}$ and kinetin treatments mostly increase the values OP which parallel with increase and soluble sugar, soluble protein and amino acids contents of shoots and roots of maize, wheat, cotton, broad bean and parsley plants with $\mathrm{NaCl}$ increasing. This related with increase water uptake by roots in these plants. The results indicated that kinetin had a more effective to shoot maize, both organs of wheat, broad bean and parsley plants in response to salinity stress while $\mathrm{GA}_{3}$ was more effective on cotton plants especially at higher levels of salinity. Thus plants strategy differed in their tolerance to salinity stress according to their species and differed also according to the different organs of the same plants and kinetin treatment induced highly positively affect than $\mathrm{GA}_{3}$ treatments. 


\section{Keywords}

\section{Osmotic Pressure, $\mathrm{GA}_{3}$ and Kinetin, $\mathrm{NaCl}$}

\section{Introduction}

Several environmental factors adversely affect plant growth development, hindering and seed germination such as water deficit, freezing, heat and salt stress. Biotic stress may be caused by numerous factors such as drought, salinity, cold, high temperature, alkalinity, heavy metal, air pollution and radiation [1]-[4]. Also, salinity has a deleterious effect on enzyme activity [5], nucleic acids, protein synthesis [6] and cell division [7]. However, plant species differ in their sensitivity or tolerance to salt stress [8]. There have been numerous studies of the effects of salinity on plants [9]. At the latest years, investigations have focused more on salt tolerance mechanisms in plants [10]. Some researchers have used exogenous application of biofertlizers as PGRs for reducing or eradicating the saline injury in plants [11]. Phytohormones are natural products and playing important roles in stress responses and adaptation [12]. It is thought that the repressive effect of salinity on seed germination and plant growth could be related to a lowering of endogenous concentrations of plant growth hormones [13]. Wang et al. (2001) [14] clearly defined that ABA and JA would be elevated in response to salinity, whereas other hormones as indole-3-acetic acid (IAA) and salicylic acid (SA) were lowered. For example, the exogenous application of PGRs, auxins [15], gibberellins [16], cytokinins [17] produces improves plant seed germination, growth, development and seed yields and yield quality under salinity stress [18]-[22].

In this investigation, the role of phytohormones ( $\mathrm{GA}_{3}$ or kinetin) in alleviating salinity stress in crop plants (maize, wheat, broad bean, cotton and parsley plants has been discussed.

\section{Material and Methods}

\subsection{Experimental Sites}

Five plant species Maize (Zea mays), Wheat (Triticum aestivum), Broad bean (Vicia faba), Cotton (Gossypium herbaceum) and Parsley plants (Petroselinum crispum) were grown in plastic pots in the soil without $\mathrm{NaCl}$ (control) and under salinization levels corresponding to osmotic potential of $\mathrm{NaCl}$ solution $-0.3,-0.6,-0.9$, and -1.2 MPa. Saline solutions were added to the soil in such a way that the soil solution acquired the assigned salinization levels at field capacity.

\subsection{Salinity and Phytohormonal Treatments}

Treatments of plants with saline solutions began when seedlings were two weeks old. The salinized and non-salinized plants were irrigated every other day with 1/10 Pfeffer's nutrient solution for two weeks. Then $\mathrm{GA}_{3}$ and kinetin (100 ppm) solutions were sprayed three times (5 intervals) by spraying the shoot system of the growing plants (each pot with $10 \mathrm{~cm}^{3}$ of $\mathrm{GA}_{3}$ or kinetin solutions). The control plants were sprayed with distilled water. A week after the plants was used for analysis.

\subsection{Laboratory Analysis for Metabolities}

Dry matter was determined after drying plants in an aerated oven at $70 \mathrm{C}$ to constant mass. Saccharides were determined by the anthrone-sulfuric acids method [23]. Free amino acids, proline and a soluble protein contents were measured according to [24] and [25] respectively. The osmotic potential of tissue sap was measured by advanced wide-range Osmometer 3W2.

\section{Statistical Analysis}

The data of all experiments were subjected to one way analysis variance and means were compared using the least significant difference test (L.S.D.) using statistical program (Sta. Base. Exe.) on computer [26]. 


\section{Results}

The data represented in Table 1 explain that soluble sugar remained more or less unchanged up to the level -0.6 $\mathrm{MPa}$, after that it was considerably increased in shoot of maize plant. In root a reduction was observed with rise of osmotic of osmotic stress (Table 1), the percent of reduction was $48.1 \%$ than control plants. In wheat plants soluble sugar content was markedly decrease in shoots while this content slightly increased up to $-0.9 \mathrm{MPa}$ in roots, after that a reduction was observed at $-1.2 \mathrm{MPa}$ (Table 2). The percent of reduction was $16.1 \%, 14.1 \%$ at $-1.2 \mathrm{MPa} \mathrm{NaCl}$ levels in shoots and roots respectively than the control plants. The production of soluble sugars was significantly increased with increasing osmotic stress in shoots and roots of cotton plants (Table 3). Except of this trend the production of soluble sugar at -1.2 MPa in roots of cotton plants which was markedly decreased than control plants. It was observed that soluble sugar was significantly decreased starting from $-0.3 \mathrm{MPa}$ to $-1.2 \mathrm{MPa}$ in shoots and roots of broad bean plants (Table 4). The percent of reduction was $62.7 \%$ and $2.7 \%$, in shoots and roots of broad bean respectively, this indicate that reduction was more in shoots than in roots. In parsley plants the contents of soluble sugar were decreased in roots while it exhibited a pronounced accumulation in shoot of plants grown at the level-0.3 MPa, 0.6 MPa and -0.9 MPa osmotic stress levels. Wheras a reduction was observed at $-1.2 \mathrm{MPa} \mathrm{NaCl}$ levels. The percent of reduction was $6.2 \%, 35.2 \%$ in shoots and roots of parsley plants i.e. root was more effect with osmotic stress in opposite to broad bean plants (Table 5). The osmotic stress stimulated the accumulation of soluble protein in shoots of maize plants while in roots these contents remain more or less unchanged up to $-0.6 \mathrm{MPa}$ osmotic stresses, after that they were considerably decreased (Table 1). The percent of reduction was $18.8 \%$ and $39.8 \%$ at 0.9 and $-1.2 \mathrm{MPa} \mathrm{NaCl}$ levels in maize roots. Increasing osmotic stress resulted in a considerable accumulation in soluble protein in shoots and roots of wheat plants (Table 2). Except, in roots of plants grown in $-1.2 \mathrm{MPa}$, these contents were significantly reduced compared with control plants. There was a significant accumulation of soluble protein in both organs of cotton plants (Table 3). Whereas this content was markedly decreased at $-1.2 \mathrm{MPa} \mathrm{NaCl}$ levels as compared with control plants. Soluble protein content decreased in shoots and in roots, this reduction was run slightly up to -0.9 $\mathrm{MPa}$, after that it lower progressively at $-1.2 \mathrm{MPa}$ of broad bean plants, (Table 4). Increasing osmotic stress

Table 1. Analysis for soluble sugar soluble and amino acids contents of shoot and root of maize plants.

\begin{tabular}{|c|c|c|c|c|c|c|c|c|c|}
\hline \multirow[t]{2}{*}{ Treat. } & \multirow{2}{*}{$\begin{array}{c}\mathrm{NaCl} \\
-\mathrm{MPa}\end{array}$} & \multicolumn{2}{|c|}{$\begin{array}{l}\text { Soluble sugar } \\
\left(\mathrm{mg} \mathrm{g}^{-1} \text { d.m.) }\right.\end{array}$} & \multicolumn{2}{|c|}{$\begin{array}{l}\text { Soluble protein } \\
\text { (mg g }{ }^{-1} \text { d.m.) }\end{array}$} & \multicolumn{2}{|c|}{$\begin{array}{l}\text { Amino acids } \\
\left(\mathrm{mg} \mathrm{g}^{-1} \text { d.m.) }\right.\end{array}$} & \multicolumn{2}{|c|}{ Water content } \\
\hline & & Shoot & Root & Shoot & Root & Shoot & Root & Shoot & Root \\
\hline \multirow[t]{5}{*}{0} & 0.0 & 45.6 & 20.8 & 97.5 & 55.3 & 6.2 & 2.3 & 24.9 & 3.6 \\
\hline & 0.3 & 43.1 & 17.4 & 107.9 & 56.1 & 5.3 & 3.4 & 24.3 & 2.5 \\
\hline & 0.6 & 42.1 & 18.9 & 118.5 & 56.0 & 10.2 & 3.5 & 20. & 3.1 \\
\hline & 0.9 & 51.9 & 12.5 & 111.4 & 44.9 & 14.4 & 4.6 & 17.5 & 3.0 \\
\hline & 1.2 & 50.4 & 10.8 & 115.1 & 34.9 & 9.4 & 4.5 & 18.7 & 1.7 \\
\hline \multirow[t]{5}{*}{$\mathrm{GA}_{3}$} & 0.0 & 50.9 & 20.8 & 105.0 & 56.2 & 6.5 & 2.3 & 30.4 & 3.7 \\
\hline & 0.3 & 52.1 & 18.2 & 141.3 & 56.4 & 7.9 & 1.7 & 27.1 & 4.8 \\
\hline & 0.6 & 56.2 & 18.0 & 126.6 & 55.4 & 7.9 & 1.1 & 22.9 & 6.3 \\
\hline & 0.9 & 56.2 & 16.2 & 129.2 & 54.2 & 12.0 & 0.979 & 25.1 & 4.3 \\
\hline & 1.2 & 58.5 & 15.9 & 104.1 & 58.2 & 8.3 & 0.839 & 21.1 & 2.9 \\
\hline \multirow[t]{5}{*}{ Kin. } & 0.0 & 88.9 & 21.1 & 180.4 & 67.6 & 6.2 & 1.1 & 31.3 & 3.9 \\
\hline & 0.3 & 104.3 & 21.4 & 197.7 & 67.1 & 7.8 & 1.2 & 28.8 & 4.3 \\
\hline & 0.6 & 105 & 27.1 & 247.0 & 68.9 & 7.7 & 1.3 & 28.9 & 4.2 \\
\hline & 0.9 & 111 & 27.4 & 257.9 & 55.7 & 7.6 & 1.1 & 28.9 & 3.8 \\
\hline & 1.2 & 108 & 27.4 & 265.3 & 40.9 & 2.9 & 1.1 & 23.3 & 2.8 \\
\hline L.S.D. 5\% & & 4.7 & 2.3 & 1.6 & 1.5 & 1.4 & 0.80 & 1.3 & 1.0 \\
\hline
\end{tabular}


Table 2. Analysis for soluble sugar soluble and amino acids contents of shoot and root of wheat plants.

\begin{tabular}{|c|c|c|c|c|c|c|c|c|c|}
\hline \multirow[t]{2}{*}{ Treat. } & \multirow{2}{*}{$\begin{array}{c}\mathrm{NaCl} \\
-\mathrm{MPa}\end{array}$} & \multicolumn{2}{|c|}{$\begin{array}{l}\text { Soluble sugar } \\
\text { (mg g }{ }^{-1} \text { d.m.) }\end{array}$} & \multicolumn{2}{|c|}{$\begin{array}{l}\text { Soluble protein } \\
\text { (mg g }{ }^{-1} \text { d.m.) }\end{array}$} & \multicolumn{2}{|c|}{$\begin{array}{l}\text { Amino acids } \\
\text { (mg g }{ }^{-1} \text { d.m.) }\end{array}$} & \multicolumn{2}{|c|}{ Water content } \\
\hline & & Shoot & Root & Shoot & Root & Shoot & Root & Shoot & Root \\
\hline \multirow[t]{5}{*}{0} & 0.0 & 43.6 & 25.2 & 104.3 & 25.8 & 9.5 & 2.9 & 6.5 & 1.9 \\
\hline & 0.3 & 41.2 & 28.3 & 125.3 & 53.4 & 7.8 & 1.6 & 7.7 & 1.4 \\
\hline & 0.6 & 38.8 & 27.9 & 111.4 & 36.6 & 8.0 & 1.2 & 7.3 & 1.4 \\
\hline & 0.9 & 36.7 & 26.5 & 120.2 & 26.3 & $4 . .8$ & 1.4 & 4.4 & 1.2 \\
\hline & 1.2 & 36.6 & 21.9 & 129.2 & 22.4 & 4.9 & 1.3 & 5.1 & 1.4 \\
\hline \multirow[t]{5}{*}{$\mathrm{GA}_{3}$} & 0.0 & 60.8 & 28.9 & 134.9 & 25.5 & 9.5 & 3.1 & 12.1 & 2.3 \\
\hline & 0.3 & 43.9 & 28.5 & 134.2 & 25.7 & 7.5 & 4.5 & 10.6 & 1.7 \\
\hline & 0.6 & 39.8 & 29.7 & 136.0 & 25.2 & 8.0 & 3.2 & 8.4 & 1.5 \\
\hline & 0.9 & 38.5 & 27.9 & 120.1 & 24.2 & 5.0 & 3.6 & 8.5 & 2.6 \\
\hline & 1.2 & 50.6 & 26.1 & 127.0 & 32.6 & 5.1 & 3.0 & 9.4 & 2.2 \\
\hline \multirow[t]{5}{*}{ Kin. } & 0.0 & 67.3 & 24.9 & 105.0 & 30.9 & 3.2 & 2.9 & 9.2 & 2.5 \\
\hline & 0.3 & 67.1 & 28.8 & 104.2 & 40.0 & 2.6 & 1.8 & 9.8 & 2.3 \\
\hline & 0.6 & 59.7 & 28.7 & 103.8 & 37.8 & 6.1 & 1.6 & 9.4 & 1.7 \\
\hline & 0.9 & 68.5 & 26.4 & 116.6 & 35.4 & 7.3 & 1.7 & 7.9 & 1.8 \\
\hline & 1.2 & 68.5 & 26.2 & 134.2 & 30.6 & 4.9 & 1.8 & 7.1 & 1.8 \\
\hline L.S.D. 5\% & & 0.96 & 0.679 & 1.7 & 0.998 & 1.0 & 0.368 & 1.1 & 0.85 \\
\hline
\end{tabular}

Table 3. Analysis for soluble sugar soluble and amino acids contents of shoot and root of cotton wheat plants.

\begin{tabular}{|c|c|c|c|c|c|c|c|c|c|}
\hline \multirow[t]{2}{*}{ Treat. } & \multirow{2}{*}{$\begin{array}{l}\mathrm{NaCl} \\
-\mathrm{MPa}\end{array}$} & \multicolumn{2}{|c|}{$\begin{array}{l}\text { Soluble sugar } \\
\text { (mg g }{ }^{-1} \text { d.m.) }\end{array}$} & \multicolumn{2}{|c|}{$\begin{array}{l}\text { Soluble protein } \\
\text { (mg g }{ }^{-1} \text { d.m.) }\end{array}$} & \multicolumn{2}{|c|}{$\begin{array}{l}\text { Amino acids } \\
\text { (mg g }{ }^{-1} \text { d.m.) }\end{array}$} & \multicolumn{2}{|c|}{ Water content } \\
\hline & & Shoot & Root & Shoot & Root & Shoot & Root & Shoot & Root \\
\hline \multirow[t]{5}{*}{0} & 0.0 & 82.3 & 46.5 & 155.5 & 138.1 & 7.6 & 1.9 & 23.2 & 4.8 \\
\hline & 0.3 & 92.9 & 63.2 & 165.1 & 157.5 & 6.6 & 2.3 & 24.3 & 3.9 \\
\hline & 0.6 & 93.1 & 56.7 & 174.7 & 173.4 & 5.9 & 2.4 & 21.7 & 3.9 \\
\hline & 0.9 & 94.0 & 183.5 & 176.5 & 138.8 & 5.1 & 2.9 & 20.2 & 2.0 \\
\hline & 1.2 & 98.2 & 141.5 & 141.9 & 93.9 & 4.9 & 2.9 & 21.8 & 1.7 \\
\hline \multirow[t]{5}{*}{$\mathrm{GA}_{3}$} & 0.0 & 56.9 & 54.1 & 206.1 & 36.2 & 7.7 & 3.9 & 25.2 & 5.4 \\
\hline & 0.3 & 51.5 & 115.7 & 235.9 & 56.4 & 9.1 & 6.3 & 26.9 & 5.4 \\
\hline & 0.6 & 72.5 & 109.7 & 242.0 & 55.4 & 8.7 & 5.9 & 29.6 & 4.8 \\
\hline & 0.9 & 58.9 & 151.9 & 260.3 & 54.2 & 9.5 & 13.6 & 19.5 & 5.0 \\
\hline & 1.2 & 49.6 & 109.3 & 220.0 & 48.2 & 6.3 & 18.6 & 17.5 & 5.0 \\
\hline \multirow[t]{5}{*}{ Kin. } & 0.0 & 82.9 & 60.8 & 214.3 & 100.2 & 12.9 & 4.2 & 24.7 & 3.9 \\
\hline & 0.3 & 97.1 & 113.2 & 198.0 & 160.5 & 8.9 & 4.7 & 25.2 & 4.7 \\
\hline & 0.6 & 97.9 & 123.4 & 209.4 & 180.5 & 8.2 & 5.5 & 24.6 & 4.7 \\
\hline & 0.9 & 98.7 & 125.9 & 220.9 & 180.4 & 8.2 & 7.0 & 23.5 & 4.8 \\
\hline & 1.2 & 100.9 & 52.9 & 192.9 & 180.6 & 8.4 & 6.2 & 20.7 & 3.7 \\
\hline L.S.D. 5\% & & 4.2 & 4.5 & 1.6 & 1.88 & 0.862 & 1.5 & 1.0 & 0.8 \\
\hline
\end{tabular}


Table 4. Analysis for soluble sugar soluble and amino acids contents of shoot and root of broad bean plants plants.

\begin{tabular}{|c|c|c|c|c|c|c|c|c|c|}
\hline \multirow[t]{2}{*}{ Treat. } & \multirow{2}{*}{$\begin{array}{l}\mathrm{NaCl} \\
-\mathrm{MPa}\end{array}$} & \multicolumn{2}{|c|}{$\begin{array}{l}\text { Soluble sugar } \\
\text { (mg g }{ }^{-1} \text { d.m.) }\end{array}$} & \multicolumn{2}{|c|}{$\begin{array}{l}\text { Soluble protein } \\
\text { (mg g g }{ }^{-1} \text { d.m.) }\end{array}$} & \multicolumn{2}{|c|}{$\begin{array}{l}\text { Amino acids } \\
\text { (mg g }{ }^{-1} \text { d.m.) }\end{array}$} & \multicolumn{2}{|c|}{ Water content } \\
\hline & & Shoot & Root & Shoot & Root & Shoot & Root & Shoot & Root \\
\hline \multirow[t]{5}{*}{0} & 0.0 & 28.4 & 33.9 & 303.0 & 78.0 & 12.3 & 11.3 & 25.6 & 3.2 \\
\hline & 0.3 & 37.6 & 32.6 & 294.1 & 77.1 & 14.3 & 10.1 & 24.9 & 3.3 \\
\hline & 0.6 & 41.0 & 32.5 & 225.1 & 74.0 & 18.9 & 9.8 & 24.5 & 2.8 \\
\hline & 0.9 & 37.8 & 32.8 & 217.2 & 70.8 & 19.9 & 8.9 & 21.7 & 2.6 \\
\hline & 1.2 & 33.8 & 33.0 & 210.0 & 32.4 & 25.4 & 9.8 & 22.7 & 1.6 \\
\hline \multirow[t]{5}{*}{$\mathrm{GA}_{3}$} & 0.0 & 128.8 & 48.3 & 345.6 & 135.1 & 29.1 & 17.3 & 26.1 & 6.0 \\
\hline & 0.3 & 126.5 & 66.1 & 340.7 & 12.5 & 21.2 & 17.0 & 25.7 & 6.1 \\
\hline & 0.6 & 90.9 & 50.9 & 300.4 & 78.8 & 29.6 & 15.2 & 27.9 & 7.5 \\
\hline & 0.9 & $90 . .2$ & 50.6 & 300.6 & 79.4 & 25.8 & 15.5 & 25.1 & 8.0 \\
\hline & 1.2 & 106.8 & 50.9 & 300.9 & 82.2 & 21.4 & 12.8 & 22.6 & 5.8 \\
\hline \multirow[t]{5}{*}{ Kin. } & 0.0 & 93.5 & 38.1 & 313.5 & 91.3 & 32.6 & 16.3 & 26.9 & 6.1 \\
\hline & 0.3 & 97.3 & 38.9 & 318.3 & 145.9 & 36.4 & 15.6 & 26.5 & 6.0 \\
\hline & 0.6 & 109.9 & 55.9 & 318.9 & $160 . .1$ & 26.9 & 16.7 & 25.3 & 6.1 \\
\hline & 0.9 & 97.9 & 68.9 & 375.3 & 124.6 & 30.3 & 16.2 & 22.2 & 5.0 \\
\hline & 1.2 & 98.1 & 66.2 & 349.7 & 120.9 & 24.6 & 12.5 & 22.2 & 5.3 \\
\hline L.S.D. 5\% & & 5.9 & 5.3 & 1.8 & 1.7 & 1.6 & 1.6 & 2.1 & 1.1 \\
\hline
\end{tabular}

Table 5. Analysis for soluble sugar soluble and amino acids contents of shoot and root of parsley plants plants.

\begin{tabular}{|c|c|c|c|c|c|c|c|c|c|}
\hline \multirow[t]{2}{*}{ Treat. } & \multirow{2}{*}{$\begin{array}{l}\mathrm{NaCl} \\
-\mathrm{MPa}\end{array}$} & \multicolumn{2}{|c|}{$\begin{array}{l}\text { Soluble sugar } \\
\text { (mg g }{ }^{-1} \text { d.m.) }\end{array}$} & \multicolumn{2}{|c|}{$\begin{array}{l}\text { Soluble protein } \\
\text { (mg g }{ }^{-1} \text { d.m.) }\end{array}$} & \multicolumn{2}{|c|}{$\begin{array}{l}\text { Amino acids } \\
\text { ( } \mathrm{mg} \mathrm{g}^{-1} \text { d.m.) }\end{array}$} & \multicolumn{2}{|c|}{ Water content } \\
\hline & & Shoot & Root & Shoot & Root & Shoot & Root & Shoot & Root \\
\hline \multirow[t]{5}{*}{0} & 0.0 & 79.3 & 55.2 & 96.4 & 46.9 & 8.9 & 102.6 & 5.5 & 1.3 \\
\hline & 0.3 & 68.6 & 60.2 & 97.4 & 55.9 & 8.3 & 6.7 & 5.3 & 1.3 \\
\hline & 0.6 & 87.3 & 37.7 & 106.9 & 55.9 & 8.2 & 6.9 & 5.2 & 1.2 \\
\hline & 0.9 & 87.6 & 34.3 & 108.9 & 49.9 & 8.8 & 6.4 & 5.9 & 1.2 \\
\hline & 1.2 & 71.4 & 36.3 & 114.5 & 44.3 & 9.0 & 6.3 & 5.1 & 1.9 \\
\hline \multirow[t]{5}{*}{$\mathrm{GA}_{3}$} & 0.0 & 132.2 & 83.3 & 109.8 & 47.1 & 8.9 & 12.7 & 26.1 & 6.0 \\
\hline & 0.3 & 111.8 & 84.9 & 117.4 & 47.1 & 8.5 & 5.6 & 25.7 & 6.1 \\
\hline & 0.6 & 126.1 & 78.3 & 129.9 & 46.0 & 9.8 & 5.6 & 27.9 & 7.5 \\
\hline & 0.9 & 135.4 & 67.9 & 129.7 & 49.5 & 8.6 & 5.5 & 25.1 & 8.0 \\
\hline & 1.2 & 178.4 & 89.2 & 129.1 & 46.7 & 5.5 & 5.9 & 25.6 & 5.8 \\
\hline \multirow[t]{5}{*}{ Kin. } & 0.0 & 77.2 & 52.9 & 153.9 & 168.1 & 2.4 & 2.8 & 5.8 & 1.3 \\
\hline & 0.3 & 77.1 & 77.6 & 137.8 & 142.9 & 2.3 & 1.8 & 5.8 & 2.1 \\
\hline & 0.6 & 89.9 & 65.2 & 135.1 & 56.2 & 3.9 & 2.5 & 6.4 & 1.8 \\
\hline & 0.9 & 85.4 & 44.4 & 113.8 & 55.5 & 4.1 & 2.8 & 6.7 & 1.4 \\
\hline & 1.2 & 93.6 & 44.4 & 96.8 & 56.2 & 4.3 & 3.6 & 5.9 & 1.7 \\
\hline L.S.D. 5\% & & 9.7 & 11.1 & 1.1 & 1.4 & 1.3 & 0.913 & 0.91 & 0.53 \\
\hline
\end{tabular}


accumulated soluble protein of shoots and roots of parsley plants while a slightly decrease was observed at -1.2 MPa NaCl level (Table 5). The data represented in Table 1 and Table 2 showed that while osmotic stress accumulated the amino acids in shoots and roots of maize plants, induced in most cases a reduction in these accumulation in shoots and roots of wheat and parsley plants when compared with control plants (Table 2, Table 5). Except of this trend amino acid run in stable values in shoot of parsley plant. The accumulation of amino acids contents run in opposite directions of shoots and roots of cotton and broad bean plants. It was significantly increased in root cotton and shoots broad bean plants, while tended to decrease in shoot cotton and root broad bean plants (Table 3, Table 4). The values of OP were significantly elevated in shoots and roots of maize, wheat and cotton plants (Figure 1(a), Figure 1(b), Figure 2(a), Figure 2(b) and Figure 3(a), Figure 3(b)). The percent of increase at $-1.2 \mathrm{MPa} \mathrm{NaCl}$ was $58.3 \%$, 35\% for shoot and root of maize plant, $34.9 \%$ and $13.3 \%$ of shoots and roots of wheat plants and $32.1 \%$ for cotton shoots plants. The OP values of root cotton reach 6.5-folds at $-1.2 \mathrm{MPa} \mathrm{NaCl}$ level than the values of control plants (100\%). In broad bean plants OP was markedly decreased in both shoots and roots (Figure 4(a), Figure 4(b)). The percent of reduction was 24.8\%, 21.9\% of shoot and root of broad bean plants at $-1.2 \mathrm{MPa} \mathrm{NaCl}$ levels compared with control plants. In parsley plant while OP remains unchanged in shoot, it was markedly decrease in root, the percent of reduction was $52.1 \%$ when compared with untreated plants (Table 5). Hormonal treatments $\left(\mathrm{GA}_{3}\right.$ or kinetin $\left.200 \mathrm{ppm}\right)$ stimulated the accumulation the soluble sugar of both organs of maize plants. Except of this trend $\mathrm{GA}_{3}$ treatment in root organs, the soluble sugar showed no different changes (Table 1). However, phytohormonal application increased the contents of protein in shoots and roots as compared with the corresponding levels of salinity. It is worthy to mention that kinetin application induce a pronounced accumulation reach to 2-folds in shoot soluble sugar and shoot soluble protein of both organs of maize plants (Table 1). Phytohormonal treatments decreased the amino contents in shoots and roots of maize plants compared with untreated plants (Table 1). GA 3 and kinetin induced in most cases, a pronounced increase in the production of soluble sugar, soluble protein on shoots and roots of

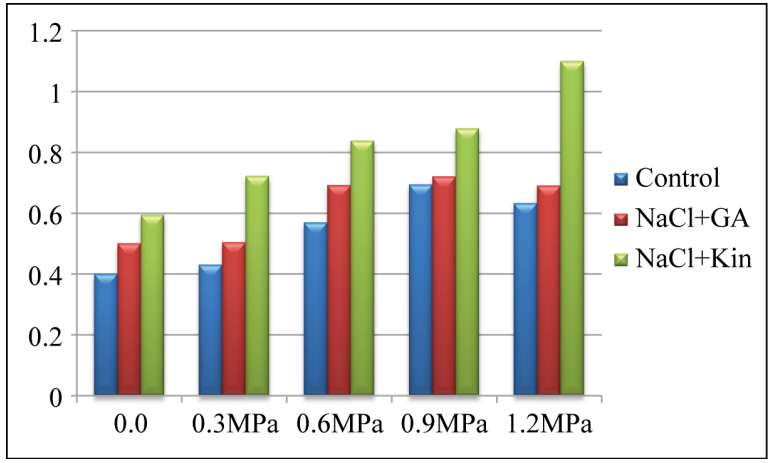

L. S. D. $5 \%$ : 0.5

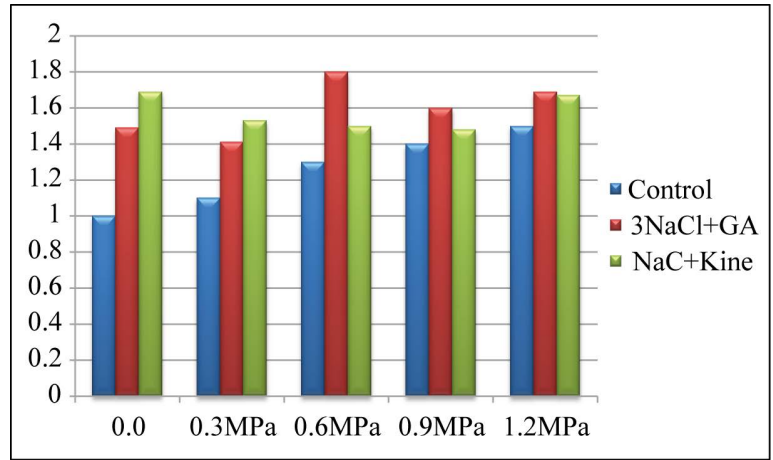

L. S. D. $5 \%: 0.1$

(a)

(b)

Figure 1. Analysis for plants on osmotic pressure (-MPa) of shoot (a) and root (b) maize plants.

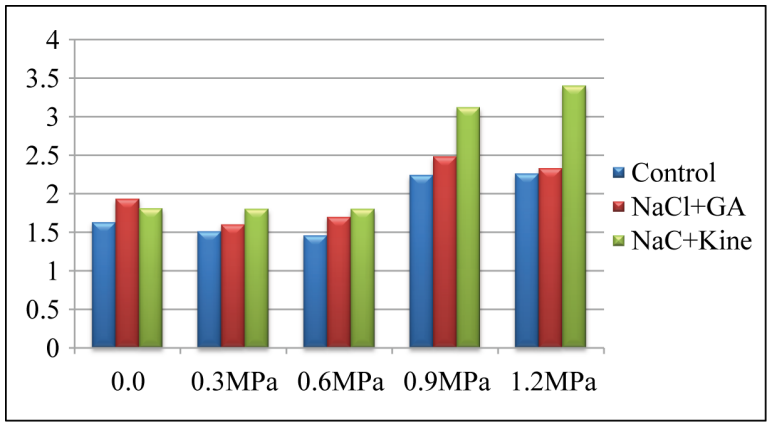

L. S. D. 5\%: 0.3

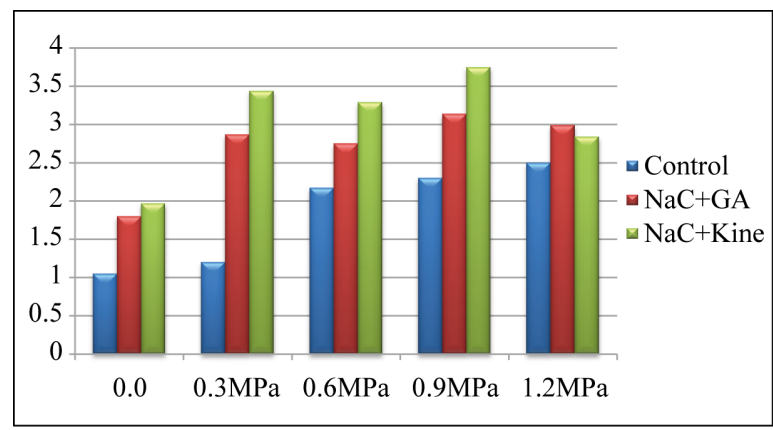

L. S. D. 5\%: 0.2

(a)

(b)

Figure 2. Analysis for plants on osmotic pressure (-MPa) of shoot (a) and root (b) wheat plants. 
wheat plant (Table 2). Whereas amino acids content remain more or less unchanged of both organs except in root wheat plants treated with $\mathrm{GA}_{3}$ they were increased when compared with untreated plants. A significant accumulation mostly was observed in the accumulation of soluble sugar, soluble protein and amino acids of shoots and roots of cotton plants, reach about 7-folds in root of plant treated with $\mathrm{GA}_{3}$ than control plants (Table 3). Phytohormonal application induced in most cases an accumulation in soluble sugar, protein and amino acids of shoot and root of broad bean and parsley plants (Table 4 \& Table 5). Except of this trend amino acids in shoot and root of parsley plants tended to decrease with increasing osmotic stress compared with untreated plants (Table 5). Spraying vegetative parts with $\mathrm{GA}_{3}$ or kinetin of 5 tested plants was elevated the OP in shoot cotton, root parsley, shoot and root broad bean, shoot maize compared with untreated plants (Figure 1, Figure 5(a), Figure 5(b)).

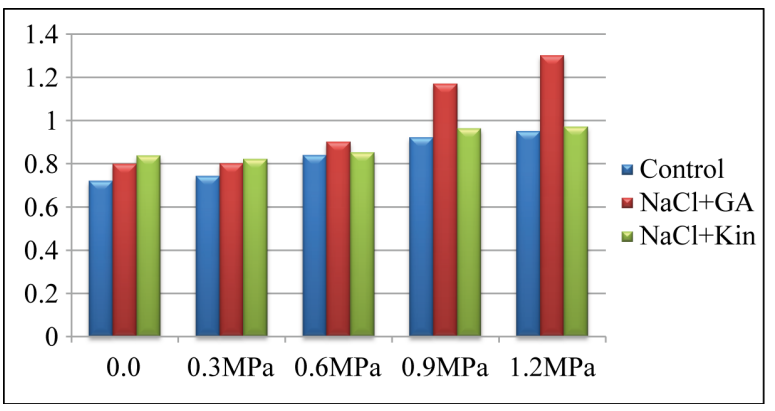

L. S. D. 5\%: 0.4

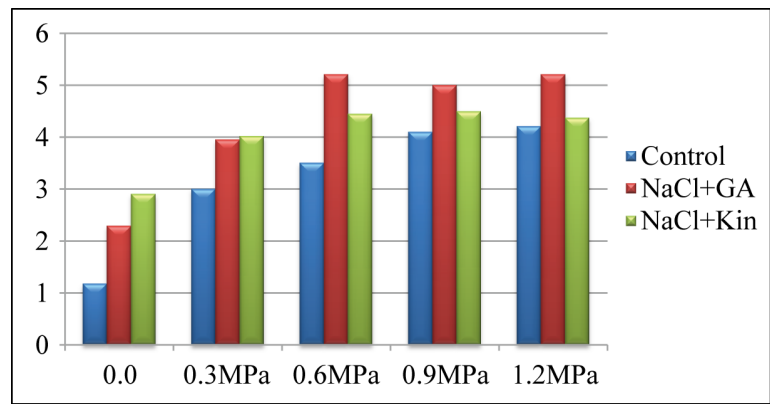

L. S. D. $5 \%: 0.2$

(a)

(b)

Figure 3. Analysis for plants on osmotic pressure (-MPa) of shoot (a) and root (b) cotton plants.

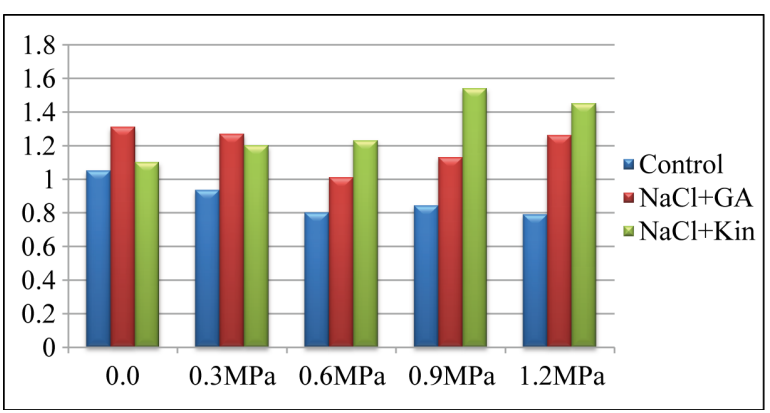

L. S. D. 5\%: 0.25

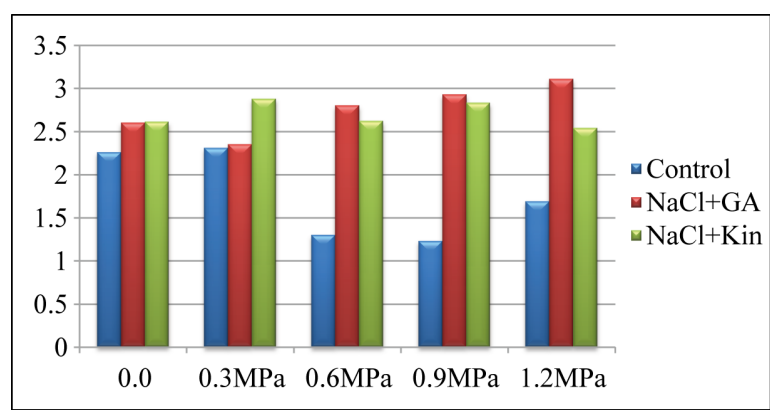

L. S. D. 5\%: 0.15

(a)

(b)

Figure 4. Analysis for plants on osmotic pressure (-MPa) of shoot (a) and root (b) broad bean plants.

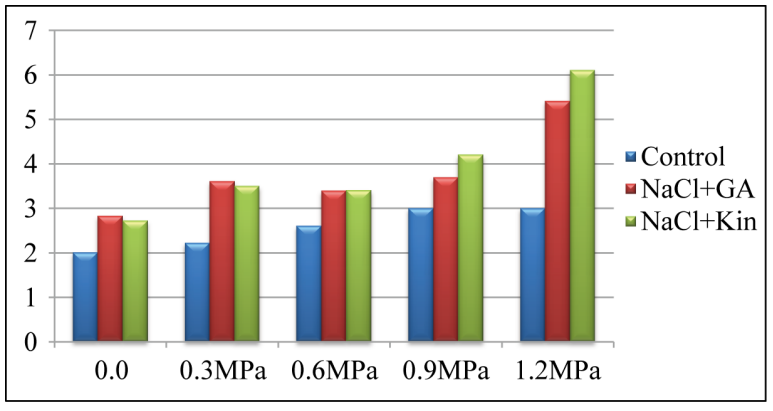

L. S. D. 5\%: 0.16

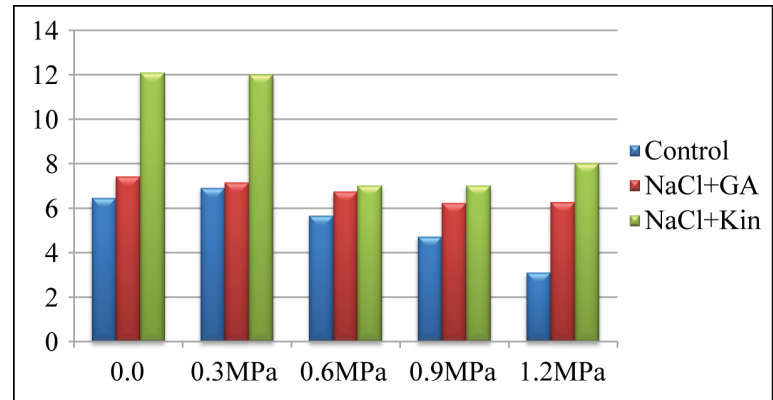

L. S. D. $5 \%$ : 0.20

(a)

(b)

Figure 5. Analysis for plants on osmotic pressure (-MPa) of shoot (a) and root (b) parsley plants. 


\section{Discussion}

The high soil salinity affected the soil penetration, decreased the soil water potential and finally caused physiological drought The plants under salinity condition change their metabolism to overcome the changed environmental condition [27]. One mechanisms utilized by the plants for overcoming the salt stress effects might be via accumulation of compatible osmolytes, such as soluble sugar. Production and accumulation of free amino acids, especially proline by plant tissue during drought, salt and water stress is an adaptive response. The osmotic pressure represented as a sign of plant tolerance or sensitive to salinity stress [28]. In the following plants the increase in OP seems to be a manner of defense mechanism to survive. OP increased in shoots of maize, shoot and root of wheat and cotton plants was concomitant with shoot soluble sugar, root soluble protein and shoot and root amino acids of maize plants. However, in wheat the increase in OP was related with increase of root soluble sugar and protein of shoots and roots. In cotton plants the elevation of OP was run parallel with increase soluble sugar of shoots and roots, shoot soluble protein and root amino acids. The increase in OP was related with a marked and significant reduction in the water content of these plants. The percent of reduction in water content at 1.2 MPa NaCl level was 24.9\%, 52.9\%, 22.2\%, 28.4\%, 9.7\%, 45.7\% of shoots and roots of maize, wheat and cotton plants respectively. i.e. the root was more sensitive than shoots in the same plants because the root was the direct organ exposed to salinity injury [29] [30]. However, the decrease in OP of shoot and root of broad bean was related with the reduction of shoots and roots soluble sugar, protein and root amino acids of broad bean. While the OP become more or less unchanged in shoots and tended to decrease in root of parsley plants, this concomitant with unchanged trend in the shoots amino acids and reduction in root soluble sugar and root amino acids. Run with previous trend values of OP and metabolites of parsley plants were related with stable values in shoot water content and reduction in root water content. It is worthy to point that the increase of soluble sugar in shoot maize, root wheat, shoot and root cotton and shoot parsley plants may be related with salt tolerance of these plants. The increasing of photosynthesis carbohydrate is a signal for water deficiency tolerance. The high carbohydrate concentration with its role to reduce water potential helps to prevent oxidative losses and protein structure maintenance during water shortage. Also carbohydrates play a molecule role for sugar responsible genes that give different physiological response like defensive response and cellular expansion [31]-[34]. The increasing of the soluble sugar during salinity stress is effective on the balance against osmotic pressure. The plant cell for escaping from plasmolysis performance and creation during salt stress conditions should be changed and analyzed from macro molecule to micro molecule. Sucrose breaks down to glucose and fructose, and starch decomposition to glucose increases its osmotic pressure cell [35]. Put the light on the OP values, while tended to increase in shoot, it decrease in root of parsley plants indicated that root was more sensitive organ than shoot to salinity stress or the metabolites translocated to shoot organ. The reduction of OP values in shoot and increase in root of broad bean plants indicated that shoot was more effective organ than root in response to osmotic stress or an accumulation of metabolites in root was recorded i.e. the metabolites and OP not distributed similarity in both shoots and roots. In between ways, there is similarity position between the response of shoot and root of maize, wheat and cotton plants OP values increase in both organs toward the salinity stress. This open the field to say that the response of plants to salinity stress not only differ between different plants but between the different organs of the same plants as parsley and broad bean plants. Other plants as wheat shoot and root response at the same manner toward salinity stress as maize, wheat and cotton plants i.e. the metabolites and OP distributed at the same way between shoots and roots. This in accordance with Hamdia and Shaddad (2013) [36]. With $\mathrm{GA}_{3}$ and kinetin treatments mostly increase the values OP which parallel with increase and soluble sugar, soluble protein and amino acids contents of shoots and roots of maize, wheat, cotton, broad bean and parsley plants with elevating $\mathrm{NaCl}$ increasing. This related with increase of water uptake by roots in these plants. The results obtained here indicated that kinetin has a more effective to shoot maize, both organs of wheat, broad bean and parsley plants in response to salinity stress while $\mathrm{GA}_{3}$ was more effective on cotton plants especially at higher levels of salinity [37]. Plant growth regulators play key role in the defensive mechanism against biotic and a biotic stresses has been confirmed. Javid et al. (2011) [38] concluded that increasing salinity is associated with decreases in auxin, cytokinin, gibberellins and SA in the plant tissues and an increase in ABA and JA. Changes in hormone levels in plant tissue are thought to be an initial process controlling growth reduction due to salinity. Therefore, $\mathrm{NaCl}$-induced reduction in the plant growth can be mitigated by application of plant growth regulators. Gibberellins (GAs) are generally involved in growth and development. They control seed germination, leaf expansion, stem elongation and flowering [39]-[42]. Exogenous application of kinetin 
overcame the effects of salinity stress on the growth of wheat seedlings [43] and treatment of potato plants with kinetin prior to salt stress diminished salt-related growth inhibition [44]. However, earlier studies reported that application of kinetin to bean plants during salinity stress exacerbated its effects [45]. Addition of benzyl adenin (BA) inhibited growth during stress of a salt-sensitive variety of barley, but overcame the decline in growth rate, shoot/root ratio and internal CK content in a salt-tolerant variety [6] [46]. Kinetin acts as a direct free radical scavenger or it may involve in antioxidative mechanism related to the protection of purine breakdown [47]. A possible involvement of genes in stress responses is often inferred from changes in the transcript abundance in response to a given stress trigger. An overview of the many changes in the transcript abundance of cytokinin genes in Arabidopsis in response to environmental factors was given elsewhere [48]. Shabala et al. (2010) [49] demonstrated that pants growth is impressed by biotic and abiotic stress inversely. There are many reports about proteins change level in salinity stress. Leaves fill up more soluble sugar of glucose, fructose and proline with treatment of salicylic acid. Thus plants strategy differed in their tolerance to salinity stress according to their species and differed also according to the different organs of the same plants and kinetin treatment induced highly positively affect than $\mathrm{GA}_{3}$ treatments.

\section{Conclusion}

The osmotic pressure represented as a sign of plant tolerance or sensitive to salinity stress. In the following plants, the increase in OP seems to be a manner of defense mechanism to survive. OP increased in shoots of maize, shoot and root of wheat and cotton plants was concomitant with shoot soluble sugar, root soluble protein and shoot and root amino acids of maize plants. However, in wheat the increase in OP was related with increase of root soluble sugar and protein of shoots and roots. In cotton plants, the elevation of OP was run parallel with increase soluble sugar of shoots and roots shoot soluble protein and root amino acids. The increase in OP was related with a marked and significant reduction in the water content of these plants. The results indicated that kinetin had a more effective to shoot maize, both organs of wheat, broad bean and parsley plants in response to salinity stress while $\mathrm{GA}_{3}$ was more effective on cotton plants especially at higher levels of salinity. Thus plants strategy differed in their tolerance to salinity stress according to their species and differed also according to the different organs of the same plants and kinetin treatment induced highly positively affect than $\mathrm{GA}_{3}$ treatments.

\section{References}

[1] Tester, M. and Davenport, R. (2003) $\mathrm{Na}^{+}$Tolerant and $\mathrm{Na}^{+}$Transport in Higher Plants. Annals of Botany, 91, $503-527$. http://www.oxfordjournals.org/our_journals/aobpla/for_authors/ http://dx.doi.org/10.1093/aob/mcg058

[2] Amuthavalli, P. and Sivasankaramoorthy, S. (2011) Effect of Salt stress on the Growth and Photosynthetic Pigments of Pigeon Pea (Cajanus cajan). Journal of Applied Pharmaceutical Science, 5, 726-734. http://www.japsonline.com/

[3] Dash, M. and Panda, S.K. (2001) Salt Stress Induced Changes in Growth and Enzyme Activities in Germinating Phaseolus muingo Seeds. Biologia Plantarum, 44, 587-589. http://dx.doi.org/10.1023/A:1013750905746

[4] Ashraf, M.Y., Sarwar, G., Ashraf, M., Afaf, R. and Sattar, A. (2002) Salinity Induced Changes in $\alpha$-Amylase Activity during Germination and Early Cotton Seedling Growth. Biologia Plantarum, 45, 589-591. http://link.springer.com/journal/10535 http://dx.doi.org/10.1023/A:1022338900818

[5] Seckin, B., Sekmen, A.H. and Turkan, I. (2009) An Enhancing Effect of Exogenous Mannitol on the Antioxidant Enzyme Activities in Roots of Wheat under Salt Stress. Journal of Plant Growth Regulation, 28, 12-20. http://dx.doi.org/10.1007/s00344-008-9068-1

[6] Anuradha, S. and Rao, S.S.R. (2001) Effect of Brassinosteroids on Salinity Stress Induced Inhibition of Seed Germination and Seedling Growth of Rice (Oryza sativa L.). Plant Growth Regulation, 33, 151-153. http://link.springer.com/journal/10725 http://dx.doi.org/10.1023/A:1017590108484

[7] Tabu, S. and Demir, K. (2010) Role of Some Growth Regulators on Cytogenetic Activity of Barley under Salt Stress. Plant Growth Regulation, 60, 99-104. http://dx.doi.org/10.1007/s10725-009-9424-6

[8] Ashraf, M. and Harris, P.J.C. (2004) Potential Biochemical Indicators of Salinity Tolerance in Plant. Plant Science, 166, 3-16. http://www.journals.elsevier.com/plant-science/ http://dx.doi.org/10.1016/j.plantsci.2003.10.024

[9] Duan, J., Li, J., Guo, S. and Kang, Y. (2008) Exogenous Spermidine Affects Polyamine Metabolism in Salinity- 
Stressed Cucumis sativus Roots and Enhances Short-Term Salinity Tolerance. Journal of Plant Physiology, 165, 16201635. http://www.journals.elsevier.com/journal-of-plant-physiology/ http://dx.doi.org/10.1016/j.jplph.2007.11.006

[10] Munns, R. and Tester, M. (2008) Mechanisms of Salinity Tolerance. Annual Review of Plant Biology, 59, 651-668. http://www.annualreviews.org/journal/arplant http://dx.doi.org/10.1146/annurev.arplant.59.032607.092911

[11] Mutlu, F. and Bozcuk, S. (2000) Tuzlu kos,ullarda ayc,ic, eği tohumların c,imlenmesi ve erken büyüme üzerine dıs, sal spermin'in etkileri. Turkish Journal of Biology, 24, 635-643.

[12] Sharma, N., Abrams, S.R. and Waterer, D.R. (2005) Uptake, Movement, Activity, and Persistence of an Abscisic Acid Analog (80 Acetylene ABA Methyl Ester) in Marigold and Tomato. Journal of Plant Growth Regulation, 24, 28-35. http://dx.doi.org/10.1007/s00344-004-0438-z

[13] Debez, A., Chaibi, W. and Bouzid, S. (2001) Effect du $\mathrm{NaCl}$ et de regulatoeurs de croissance sur la germination d' Atriplex halimus L. Cahiers Agricultures, 10, 135-138. http://fr.wikipedia.org/wiki/Cahiers Agricultures

[14] Yang, T., Davies, P.J. and Reid, J.B. (1996) Genetic Dissection of the Relative Roles of Auxin and Gibberellin in the Regulation of Stem Elongation in Intact Light-Grown Peas. Plant Physiology, 110, 1029-1034.

[15] Khan, M.A., Gul, B. and Weber, D.J. (2004) Action of Plant Growth Regulators and Salinity on Seed Germination of Ceratoides lanata. Canadian Journal of Botany, 82, 37-42. http://www.researchgate.net/journal/0008-4026_Canadian_Journal_of_Botany http://dx.doi.org/10.1139/b03-140

[16] Afzal, I., Basara, S.M.A., Faooq, M. and Nawaz, A. (2006) Alleviation of Salinity Stress in Spring Wheat by Hormonal Priming with ABA, Salicylic Acid and Ascorbic Acid. International Journal of Agriculture and Biology, 8, 23-28.

[17] Gull, B., Weber, D.J. and Khan, M.A. (2000) Effect of Salinity and Planting Density on the Physiological Response of Allenrofea occidentalis. Western North. American Naturalist, 60, 188-197. https://ojs.lib.byu.edu/spc/index.php/wnan http://www.scimagojr.com/journalsearch.php?q=10900153321\&tip=sid

[18] Sahar, K., Amin, B. and Taher, N.M. (2011) The Salicylic Acid Effect on the Salvia officianlis L. Sugar, Protein and Proline Contents under Salinity ( $\mathrm{NaCl})$ Stress. Journal of Stress Physiology \& Biochemistry, 80-87.

[19] Gomez, C.A., Arbona, V., Jacas, J., PrimoMillo, E. and Talon, M. (2002) Abscisic Acid Reduces Leaf Abscission and Increases Salt Tolerance in Citrus Plants. Journal of Plant Growth Regulation, 21, 234-240. http://dx.doi.org/10.1007/s00344-002-0013-4

[20] Gulnaz, A.J., Iqbal, J. and Azam, F. (1999) Seed Treatment with Growth Regulators and Crop Productivity. II. Response of Critical Growth Stages of Wheat (Triticum aestivum L.) under Salinity Stress. Cereal Research, 27, 419-426. http://www.bioxbio.com/if/html/CEREAL-RES-COMMUN.html.

[21] Egamberdieva, D. (2009) Alleviation of Salt Stress by Plant Growth Regulators and IAA Producing Bacteria in Wheat. Acta Physiologiae Plantarum, 31, 861-864. http://www.springer.com/life+sciences/plant+sciences/journal/11738 http://dx.doi.org/10.1007/s11738-009-0297-0

[22] Zahir, Z.A., Asghar, H.N. and Arshad, M. (2001) Cytokinin and Its Precursors for Improving Growth and Yield of Rice. Soil Biology \& Biochemistry, 33, 405-408. http://www.savenkeep.com/?q=soil\%20biol\%20biochem\&from=adg250\&rlbt=2 http://dx.doi.org/10.1016/S0038-0717(00)00145-0

[23] Fales, F.W. (1951) The Assimilation and Degradation of Carbohydrates of Yeast Cells. Journal of Biological Chemistry, 193, 113-118. http://www.degruyter.com/view/j/bchm

[24] Moore, S. and Stein, W. (1948) Photometric Ninhydrine Method for Use in the Chromatagoraphy of Amino Acid. Journal of Biological Chemistry, 17, 367-388.

[25] Lowry, O.H., Roserbrough, N.J., Farr, A.L. and Randall, R.J. (1951) Protein Measurement with the Folin Phenol Reagent. Journal of Biological Chemistry, 193, 265-275. http://en.wikipedia.org/wiki/Journal_of_Biological_Chemistry

[26] Steel, R.G. and Torrie, J.H. (1960) Principles and Procedures of Statistics. McGraw-Hill Book Co., New York.

[27] Jouyban, Z. (2012) The Effects of Salt Stress on Plant Growth. Technical Journal of Engineering and Applied Sciences, 2, 7-10. http://tjeas.com/

[28] Tari, I., Csisaa, J., Szalai, G., Horath, F., Kiss, G., Szepesi, G., Szabl, M. and Erdei, L. (2002) Acclimation of Tomato Plants to Salinity Stress after a Salicylic Acid Pre-Treatment. Acta Biologica Szegediensis, 46, 55-56. http://epa.oszk.hu/00700/00768/ismerteto.html

[29] Bernstein, N., Loffe, N. and Zilberstaine, M. (2001) Salt Stress Effects on Avocado Root Stock Growth. I. Esrablishing Crieteria or Determination of Growth Sensitivity to the Stress. Plant and Soil, 233, 1-11.

http://link.springer.com/journal/11104 
http://dx.doi.org/10.1023/A:1010370802773

[30] Bernstein, N., Meiri, A. and Zilberstaine, M. (2004) Root Growth of Avocado Is More Sensitive to Salinity than Shoot Growth. Journal of the American Society for Horticultural Science, 129, 188-192. http://journal.ashspublications.org/

[31] El-Tayeb, M.A. (2005) Response of Barley Grains to the Interactive Effect of Salinity and Salicylic Acid. Plant Growth Regulation, 45, 215-224. http://dx.doi.org/10.1007/s10725-005-4928-1

[32] Szepesi, Á. (2006) Salicylic Acid Improves the Acclimation of Lycopersicon esculentum Mill. L. to High Salinity by Approximating Its Salt Stress Response to That of the Wild Species L. pennellii. Acta Biologica Szegediensis, 50, 177. http://www.researchgate.net/journal/15884082_Acta_Biologica_Szegediensis

[33] Zahra, S., Amin, B., Ali, V., Ali, Y. and Mehdi, Y. (2010) The Salicylic Acid Effect on the Tomato (Lycopersicum esculentum Mill.) Sugar, Protein and Proline Contents under Salinity Stress (NaCl). Journal of Biophysics and Structural Biology, 2, 35-41. http://www.academicjournals.org/journal/JBSB

[34] Yusuf, M., Hasan, S.A., Ali, B., Hayat, S., Fariduddin, Q. and Ahmad, A. (2007) Effect of Salicylic Acid on Salinity Induced Changes in Brassica juncea. Journal of Integrative Plant Biology, 50, 1096-1102. http://www.jipb.net/ http://dx.doi.org/10.1111/j.1744-7909.2008.00697.x

[35] Benbella, M. (1999) Response of Five Sunflower Genotypes (Helianthus annus L.) to Different Concentrations of Sodium Chloride. Helia, 22, 125-138. http://www.doiserbia.nb.rs/journal.aspx?issn=1018-1806\&AspxAutoDetectCookieSupport=1

[36] Hamdia, M., El-Samad, A. and Shaddad, M.A.K. (2014) The Exogenous Amelioration Roles of Growth Regulators on Crop Plants Grow under Different Osmotic Potential. Journal of Stress Physiology \& Biochemistry, 10, 203-213. http://www.jspb.ru/

[37] Kabar, K. and Balted, S. (1990) Effects of Kinetin and Gibberellic Acid in Overcoming High Temperature and Salinity $(\mathrm{NaCl})$ Stresses on the Germination of Barley and Lettuce Seeds. Phyton (Horn, Austria), 30, 65-74. http://www.zobodat.at/pdf/PHY 301 0065-0074.pdf

[38] Javid, M.G., Sorooshzadeh, A., Modarres, F., Sanavy, S. and Allahdadi, I. (2011) The Role of Phytohormones in Alleviating Salt Stress in Crop Plants. Australian Journal of Crop Science, 5, 726-734.

[39] Magome, H., Yamaguchi, S., Hanada, A., Kamiya, Y. and Odadoi, K. (2004) Dwarf and Delayed-Flowering 1, a Novel Arabidopsis Mutant Deficient in Gibberellins Biosynthesis Because of over Expression of a Putative AP2 Transcription Factor. The Plant Journal, 37, 720-729. http://www.scimagojr.com/journalsearch.php?q=16612\&tip=sid http://dx.doi.org/10.1111/j.1365-313X.2003.01998.X

[40] Zhu, Y., Nomura, T., Xu, Y.O., Zhang, Y., Peng, Y., Mao, B., Hanada, A., Zhou, H., Wang, R. and Li, P. (2006) Elogated Uppermost Internode Encodes a Cytochrome P450 Monooxygenase That Epoxidizes Gibberellins in a Novel Deactivation Reaction in Rice. Plant Cell, 18, 442-456. http://biology.about.com/od/cellbiology/ss/plant-cell.htm http://dx.doi.org/10.1105/tpc.105.038455

[41] Achard, P., Cheng, H., Grauwe, L.D., Decat, J., Schoutteten, H., Moritz, T., Dominique, V.D.S., Peng, J. and Harberd, N.P. (2006) Integration of Plant Responses to Environmentally Activated Phytohormonal Signals. Science, 311, 91-94. http://www.sciencemag.org/ http://dx.doi.org/10.1126/science.1118642

[42] Sun, T.P. and Gubler, F. (2004) Molecular Mechanism of Gibberellins Signaling in Plant. Annual Review of Plant Biology, 55, 197-223. http://dx.doi.org/10.1146/annurev.arplant.55.031903.141753

[43] Naqvi, S.S.M., Ansari, R. and Kuawada, A.N. (1982) Responses of Salt Stressed Wheat Seedlings to Kinetin. Plant Science Letters, 26, 279-283. http://www.sciencedirect.com/science/journal/03044211 http://dx.doi.org/10.1016/0304-4211(82)90102-x

[44] Abdullah, Z. and Ahmad, R. (1990) Effect of Pre- and Post-Kinetin Treatments on Salt Tolerance of Different Potato Cultivars Growing on Saline Soils. Journal of Agronomy and Crop Science, 165, 94-102. http://dx.doi.org/10.1111/j.1439-037X.1990.tb00839.x

[45] Kirkham, M.B., Gardner, W.R. and Gerloff, G.C. (1974) Internal Water Status of Kinetin-Treated, Salt-Stressed Plants. Plant Physiology, 53, 241-243. http://www.ncbi.nlm.nih.gov/pubmed/16658683 http://dx.doi.org/10.1104/pp.53.2.241

[46] Kuiper, D., Schuit, J. and Kuiper, P.J.C. (1990) Actual Cytokinin Concentrations in Plant Tissue as an Indicator for Salt Resistance in Cereals. Plant and Soil, 123, 243-250.

http://www.ebay.co.uk/sch/i.html?_nkw=plant\%20soil\&clk_rvr_id=693308600755\&adpos=1s2\&MT_ID=10\&crlp=40 $\underline{544072095 \_2113181 \& \text { device }=\text { c\&geo_id }=32251 \& \text { keyword }=\text { plant }+ \text { soil\&crdt }=0}$ http://dx.doi.org/10.1007/BF00011276

[47] Chakrabarti, N. and Mukherji, S. (2003) Alleviation of NaCl Stress by Pretreatment with Phytohormones in Vigna radiata. Biologia Plantarum, 46, 589-594. http://dx.doi.org/10.1023/A:1024827931134 
[48] Argueso, C.T., Ferreira, F.J. and Kieber, J.J. (2009) Environmental Perception Avenues: The Interaction of Cytokinin and Environmental Response Pathways. Plant, Cell \& Environment, 32, 1147-1160.

http://onlinelibrary.wiley.com/journal/10.1111/(ISSN)1365-3040

http://dx.doi.org/10.1111/j.1365-3040.2009.01940.x

[49] Shabala, S., Shabala, L., Cuin, T.A., Pang, J., Percey, W., Chen, Z., Conn, S., Eing, C. and Wegner, L.H. (2010) Xylem Ionic Relations and Salinity Tolerance in Barley. The Plant Journal, 61, 839-853.

http://dx.doi.org/10.1111/j.1365-313X.2009.04110.x 